\title{
Az alkoholfogyasztás kockázati határértékének meghatározása 83 prospektív vizsgálaton keresztül
}

\author{
Risk thresholds for alcohol consumption combined analysis of individual- \\ participant data for 599912 current drinkers in 83 prospective studies
}

Ismerteti: $\quad$ Bérczi Bálint $\triangle$

PTE Általános Orvostudományi Kar, Orvosi Népegészségtani Intézet

Szerzők: Angela M Wood, Stephen Kaptoge, Adam S Butterworth és mtsai

Megjelenés: Lancet 2018; 391: 1513-23.

doi: https://doi.org/10.1016/S0140-6736(18)30134-X

Beküldve: 2018. 05. 09.

doi: $10.24365 /$ ef.v59i3.305

Kulcsszavak: alkoholfogyasztás, szív- és érrendszeri megbetegedés, mortalitás, elveszített életévek száma

Keywords: alcohol consumption, cardiovascular diseases, mortality, years of life lost

A különböző országok alkoholfogyasztásra vonatkozó irányelvei lényegesen különböznek egymástól. Az Egyesült Államok szerint hetente 196 g 99\%-os etil-alkoholnak megfelelő italmennyiséget fogyaszthatnak a férfiak, míg a nők esetében ez 98 g. Az Egyesült Királyság szerint mind a férfiak, mind a nők esetében az egy hét alatt elfogyasztott alkoholmennyiség nem haladhatja meg a 14 italegységet és legalább 3 vagy több napra egyenlő arányban kell elosztani. Az irányelv szerint az 1 italegység megfelel $250 \mathrm{ml}$ 4V/V\%-os sörnek, $76 \mathrm{ml} 13 \mathrm{~V} / \mathrm{V} \%$-os bornak, vagy $25 \mathrm{ml}$ 40V/V\%-os whiskynek, így a 14 italegység $112 \mathrm{~g}$ elfogyasztott etil-alkoholt jelent hetente. Hasonló irányelveket követ Kanada és Svédország, míg Olaszország, Portugália és Spanyolország ajánlásai az előzőekhez képest 50\%-kal több alkohol elfogyasztását teszik lehetővé.' Az irányelvek különbözősége miatt a most ismertetésre kerülő közlemény arra keresi a

' Magyarországon a férfiak számára a napi 2, míg a nők számára 1 italegység van érvényben (Táplálkozási ajánlások a magyarországi felnőtt lakosság számára, 2004, Dr. Rodler Imre) választ, mennyi az az etil-alkoholra számított alkoholfogyasztás, amely a legkisebb kockázattal jár az összes halálozásra és a szív- és érrendszeri halálokokra nézve. A tanulmány 83 prospektív elemzés 599912 olyan résztvevőjét vizsgálta, akik jelenleg fogyasztanak alkoholt és a megfigyelés kezdetén nem volt szív- és érrendszeri betegségük. Az alkoholt fogyasztókat etil-alkoholra számított alkoholfogyasztásuk alapján 8 különböző csoportba sorolták (0-25, 25-50, 50-75, 75-100, 100-150, 150-250, 250-350, $350 \mathrm{~g}$ felett/hét) és ehhez mérten határozták meg az első szív- és érrendszeri megbetegedés bekövetkezésének kockázatát és a halálozás kockázatát az összes, és hat különböző halálokra úgy, mint stroke, szívkoszorúér betegség a miokardiális infarktus kivételével, szívelégtelenség, végzetes hipertónia, végzetes aorta aneurizma, miokardiális infarktus. Ezen felül a tanulmány szerzői az alkoholbevitel egyes csoportjaiban meghatározták az elveszített életévek számát is. 
A vizsgálati csoport átlagéletkora 57 év, női résztvevőinek száma 265910 (44\%), 128085 fő (21\%) dohányzott, 50\%-uk fogyasztott 100 g-nál, 8,4\%-uk 350 g-nál több alkoholt hetente.

Az eredmények szerint az első szív- és érrendszeri megbetegedés bekövetkezésének a kockázata az egyes alkoholmennyiségek esetében klasszikus J-alakú összefüggést mutat, vagyis egy bizonyos beviteli tartományig (150-250 g/hét) a megbetegedés kockázata és az alkoholmennyiség közti kapcsolat negatív összefüggést mutat, tehát kevesebben betegedtek meg azokhoz képest, akik nem vagy alig (0-25 g/hét) fogyasztottak alkoholt. Ugyanez a lefutás jellemző azokban az esetekben is, ahol a nem miokardiális infarktusból eredő koszorúér halálozásokat vizsgálták. A kockázat az összes halálokra nézve a $100 \mathrm{~g} /$ hét mennyiségig nem növekszik, viszont onnantól az összefüggés pozitív és lineáris a bevitt mennyiséggel, vagyis minél többet iszik valaki 100 g/hét mennyiségnél, annál nagyobb a halálozás kockázata. Továbbá pozitív és lineáris összefüggést mutat a stroke, szívelégtelenség és az egyéb szív- és érrendszeri megbetegedésből eredő halálozások kockázata az alkoholmennyiséggel. Érdekes módon a vizsgált kimenetek közül a miokardiális infarktus halálozása negatív összefüggést mutatott a bevitt alkoholmennyiséggel, vagyis minél többet ivott valaki, annál kisebb volt a halálozás kockázata 100 g/hét mennyiségig, azonban az ennél nagyobb mennyiségben hetente elfogyasztott alkohol a továbbiakban nem csökkentette a halálozás kockázatát.

A vizsgálat szerzői végül meghatározták az egyes 100 g/hét feletti csoportokban (100-200, 200-350, $350 \mathrm{~g}$ felett/hét) az elveszített életévek számát azokhoz képest, akik 0-100 g/hét mennyiségben fogyasztottak alkoholt. Az eredmények szerint, aki 40 éves és rendszeresen $100 \mathrm{~g}$ felett fogyaszt alkoholt hetente, a következő elveszített életévekkel számolhat: 100-200 g/hét esetén 6 hónap, 200-350 g/hét esetében 1-2 év, 350 g/hét felett 4-5 év. Megfigyelték a vizsgálati populációban, hogy azok a férfiak, akik meghaladják az Egyesült Királyság ajánlását (112 g/hét) 1,6 évvel, akik pedig az Egyesült Államok irányelveit (196 g/hét) 2,7 évvel korábban halhatnak meg. Azok a férfiak, akik pedig kevesebb alkoholt fogyasztanak, mint 100 g hetente, 1-2 évvel tovább élnek azokhoz képest, akik meghaladják az amerikai határértéket.

\section{TANULSÁGOK A HAZAI SZAKEMBEREK SZÁMÁRA}

Az irányelvek különbözősége miatt ez a robosztus vizsgálat a nagy elemszámával és magas statisztikai megbízhatóságával jó alapot szolgáltat arra, hogyan foglaljunk állást abban a kérdésben, mennyi az a megengedhető heti alkoholmennyiség, ami nem, vagy csak nagyon csekély mértékben emeli a kockázatot. A közlemény tanulsága szerint a hetente elfogyasztott 100 g etil-alkoholnak megfelelő mennyiség emeli a legkisebb mértékben a vizsgált kimenetek teljes halálozását. Ezen belül az egyes szív- és érrendszeri betegségek esetében nincs ilyen egyöntetű összefüggés. Az ismertetett vizsgálat kellően alapos ahhoz, hogy a különböző országok újragondolják az irányelveik által javasolt határértékeket. 